\title{
Effects of Ambient Temperature on Oxygen Consumption and the Circulation in Newborn Lambs at Rest and during Hypoxemia
}

\author{
DANIEL SIDI, JAAP R. G. KUIPERS, MICHAEL A. HEYMANN, ${ }^{(29)}$ AND ABRAHAM M. RUDOLPH \\ Cardiovascular Research Institute and the Departments of Pediatrics, Physiology, Obstetrics, Gynecology and \\ Reproductive Sciences, University of California, San Francisco, California, USA
}

\section{Summary}

To assess the effects of environmental temperature on responses to hypoxemia, we studied five unsedated lambs in the first week after birth. We catheterized the carotid artery and pulmonary artery (via the jugular vein). After recovery of at least 1 day, we measured pH, blood gases, arterial and mixed venous blood $\mathrm{O}_{2}$ content, oxygen consumption $\left(\mathrm{VO}_{2}\right)$, heart rate, carotid and pulmonary arterial pressures, and cardiac output in both warm $\left(25^{\circ} \mathrm{C}\right)$ and cool $\left(17.4 \pm 1.1^{\circ} \mathrm{C}\right)$ environments. In the cool environment, with no shivering, $\mathrm{VO}_{2}$ increased $40 \%(14.9$ to $20.8 \mathrm{ml} / \mathrm{kg} / \mathrm{min})$. There were also increases of arteriovenous blood $\mathrm{O}_{2}$ content difference of $19 \%$, cardiac output of $18 \%$, and heart rate of $14 \%$. In four lambs, we studied the same variables during hypoxemia $\left(\mathrm{FiO}_{2}\right.$ $=0.09$ for $1 \mathrm{~h}$ ) at both temperatures. In the cool environment, hypoxemia produced a greater fall of $\mathrm{VO}_{2}(26 \%$ versus $6 \%)$ and arteriovenous oxygen differences (30\% versus $19 \%)$ and a smaller increase of cardiac output (8\% versus $14 \%)$ and heart rate $(26 \%$ versus $43 \%$ ). Also in the cool environment, core temperature decreased more $\left(2.1\right.$ versus $\left.0.4^{\circ} \mathrm{C}\right)$, but base deficit was the same ( -6 versus $-5 \mathrm{mEq} / \mathrm{liter}$ ). Despite the greater fall in $\mathrm{VO}_{2}$ during hypoxemia in the cool environment, the lowest value achieved was still higher than the level during normoxemia in the warm environment. Similarly, cardiac output during hypoxemia was greater in the cool than in the warm environment. These findings may explain the variability in reported normal resting values and responses to hypoxemia. Contrary to previous reports, they also indicate that during severe hypoxemia neonates have a decreased reserve of metabolic and cardiovascular responses in a cool compared with a warm environment.

Reported values for cardiac output, heart rate, and $\mathrm{VO}_{2}$ in newborn lambs at rest $(13,17,20,24,26)$ and after induced hypoxemia $(9,14,18,24)$ vary greatly. Because newborn homeothermic mammals are very sensitive to cold, we considered that this variability could be explained by differences in ambient temperature.

In normoxemic newborns, if ambient temperature is decreased only a few degrees below neutral temperature, the metabolic requirements for maintenance of core temperature increase considerably (22). Because the reserves for increasing cardiac output (13) and $\mathrm{O}_{2}$ delivery to the tissues (17) are limited during the newborn period, the extra metabolism induced by exposure to low ambient temperature could interfere with tissue oxygenation. In hypoxemic newborn humans $(19,23)$, kittens (11), and lambs (4) at low ambient temperature the extra thermogenic metabolism is inhibited and $\mathrm{VO}_{2}$ and core temperature decrease. It has been suggested that core temperature may decrease enough to reduce basal metabolism and thereby protect the tissues of the hypoxemic newborn against oxygen lack $(1,2)$.

We have studied the circulatory and metabolic effects of moderate changes in ambient temperature that could occur in a laboratory or nursery in which ambient temperature is not controlled, and address the following questions:

(1) Can the variability reported for cardiac output, heart rate, and $\mathrm{VO}_{2}$ in the newborn lamb at rest and during hypoxemia be explained by the circulatory and metabolic changes induced by relatively small differences in ambient temperature? (2) Will the changes observed at low ambient temperature be important enough to significantly affect the circulatory and metabolic reserves of the normoxemic newborn?

(3) How effectively does hypoxemia reduce the thermogenic metabolism secondary to low ambient temperature and to what extent does core temperature drop? Also, do these combined effects reduce $\mathrm{O}_{2}$ needs adequately to protect the hypoxemic newborn from tissue hypoxia?

\section{MATERIALS AND METHODS}

We studied five lambs of mixed western breed. In all instances the date of birth was documented. Within $48 \mathrm{~h}$ after birth, under local anesthesia with $0.5 \%$ lidocaine $\mathrm{HCl}$ (xylocaine), catheters were inserted into a carotid artery and a jugular vein and advanced, with pressure monitoring, to the ascending aorta and the pulmonary artery, respectively. We used a polyvinyl catheter (OD $=1.8 \mathrm{~mm}$, ID $=1.0 \mathrm{~mm}$ ) for the aorta and a $5 \mathrm{~F} \mathrm{KMA} \mathrm{thermo-}$ dilution balloon catheter for the pulmonary artery. After the operation, we returned the lambs to their mothers and they fed immediately. We allowed them to recover overnight and performed the first study on the following morning. We flushed the catheters daily with $0.9 \% \mathrm{NaCl}$ solution, and filled them with heparin solution.

For each study the lamb was removed from the ewe, weighed and placed in a sling so that it was supported in an upright position. The lamb was blindfolded so that it would be calm in the laboratory. A loosely-fitting mask was placed over its face to collect expired gas for $\mathrm{VO}_{2}$ measurement, as described previously (16). The lamb was not sedated and data were collected after allowing at least $30 \mathrm{~min}$ for adjustment to the environment. Measurements were made only when the lambs were quiet and resting. $\mathrm{VO}_{2}$, heart rate, aortic, pulmonary arterial, and right atrial pressures were measured continuously and a wedged pulmonary arterial pressure was obtained every $5 \mathrm{~min}$ by inflating the balloon catheter. Every $15 \mathrm{~min}$ for $1 \mathrm{~h}$ blood samples of $1 \mathrm{ml}$ were withdrawn slowly and simultaneously from the aorta and the pulmonary artery to determine blood gases, $\mathrm{pH}$, hemoglobin concentration, and $\mathrm{O}_{2}$ saturation, and $3 \mathrm{ml}$ of cold $\mathrm{NaCl} 0.9 \%$ was injected rapidly through the proximal hole of the thermodilution catheter for cardiac output determination. Core temperature was displayed continuously from the thermistor located at the tip of the thermodilution catheter.

Intravascular blood pressures were measured with Statham $\mathrm{P} 23 \mathrm{Db}$ pressure transducers and recorded on a Beckman direct writing recorder. Heart rate was calculated from the aortic pressure tracing. Blood gas tensions and $\mathrm{pH}$ were measured (at $39^{\circ} \mathrm{C}$ ) with 
a Radiometer blood gas analyzer and appropriate electrodes; blood $\mathrm{O}_{2}$ saturation and hemoglobin were measured with a microoximeter (Radiometer OSM-2 Hemoximeter). Blood $\mathrm{O}_{2}$ content was calculated from the product of $\mathrm{O}_{2}$ saturation, hemoglobin concentration, and a hemoglobin binding capacity of 1.36 . Studies in this laboratory have previously shown that this calculation provides accurate values for $\mathrm{O}_{2}$ content (16). Cardiac output was calculated by the direct Fick equation from $\mathrm{VO}_{2}$ and the difference between aortic and pulmonary arterial blood $\mathrm{O}_{2}$ content and also by the thermodilution method. Whenever possible the Fick measurements were used in reporting cardiac output. Because occasional rapid changes in $\mathrm{VO}_{2}$ occurred during the first $15 \mathrm{~min}$ of hypoxemia, in these instances thermodilution cardiac output measurements were reported for the $15 \mathrm{~min}$ value. The thermodilution curve was analyzed to exclude significant left-to-right shunting.

Two different series of studies were performed in the same lambs. First, measurements were made at rest breathing room air $\left(\mathrm{FiO}_{2}=0.21\right)$ in cool $\left(16-19^{\circ} \mathrm{C}\right)$ and warm $\left(25-26^{\circ} \mathrm{C}\right)$ environments. The sequence of exposure to the two ranges of temperature was randomized. Then in the second series, we compared the responses to hypoxemia at the two environmental temperatures. Baseline observations, not used for resting data, were made in either the cool or warm environment and the lambs then were exposed to a low $\mathrm{O}_{2}$ mixture $\left(\mathrm{FiO}_{2}=0.09\right)$.

For the first group of studies in room air, measurements were made on the same day after at least $30 \mathrm{~min}$ acclimatization to each of the two thermal environments and with the animals quiet. Measurements were made at 15, 30, 45, and $60 \mathrm{~min}$ and the data at these four points in time averaged (Table 1). In the hypoxemia studies, separate measurements were made 3-4 days apart and in random order for each of the two thermal environments. Control measurements were made while the lamb breathed room air. Then 9\% $\mathrm{O}_{2}$ in nitrogen, obtained from a gas mixer, was blown into a plastic bag surrounding the head and the neck. The face mask for

Table 1. Resting values in newborn lambs studied at two different environmental temperatures on the same day

\begin{tabular}{|c|c|c|c|}
\hline & $n$ & Cool & Warm \\
\hline Environmental temperature & 5 & $17.4 \pm 1.1^{1}$ & $25.6 \pm 0.4$ \\
\hline Core temperature $\left({ }^{\circ} \mathrm{C}\right)$ & 5 & $39.5 \pm 0.4$ & $39.6 \pm 0.3$ \\
\hline $\mathrm{O}_{2}$ consumption $(\mathrm{ml} / \mathrm{min} / \mathrm{kg})$ & 5 & $20.8 \pm 2.3^{1}$ & $14.9 \pm 1.3$ \\
\hline \multicolumn{4}{|l|}{ Arterial } \\
\hline $\mathrm{pH}$ & 5 & $7.42 \pm 0.03$ & $7.43 \pm 0.04$ \\
\hline $\mathrm{PCO}_{2}$ (torr) & 5 & $35 \pm 2$ & $35 \pm 2$ \\
\hline $\mathrm{PO}_{2}$ (torr) & 5 & $76 \pm 8$ & $76 \pm 7$ \\
\hline Saturation (\%) & 5 & $96 \pm 3$ & $96 \pm 3$ \\
\hline $\mathrm{O}_{2}$ content $(\mathrm{ml} / \mathrm{dl})$ & 5 & $10.7 \pm 1.0$ & $10.7 \pm 1.0$ \\
\hline \multicolumn{4}{|l|}{ Mixed Venous } \\
\hline $\mathrm{PO}_{2}$ (torr) & 4 & $24 \pm 1^{1}$ & $29 \pm 1$ \\
\hline Saturation $(\%)$ & 4 & $39 \pm 4^{1}$ & $49 \pm 6$ \\
\hline $\mathrm{O}_{2}$ content $(\mathrm{ml} / \mathrm{dl})$ & 4 & $4.6 \pm 0.4^{1}$ & $5.5 \pm 0.5$ \\
\hline$(\mathrm{A}-\mathrm{V}) \mathrm{O}_{2}$ content $(\mathrm{ml} / \mathrm{dl})$ & 4 & $6.2 \pm 0.5^{1}$ & $5.2 \pm 0.4$ \\
\hline Cardiac output $(\mathrm{ml} / \mathrm{min} / \mathrm{kg})$ & 5 & $342 \pm 51^{2}$ & $290 \pm 44$ \\
\hline Heart rate (beats/min) & 5 & $226 \pm 16^{2}$ & $198 \pm 20$ \\
\hline Stroke volume $(\mathrm{ml} / \mathrm{kg})$ & 5 & $1.5 \pm 0.2$ & $1.5 \pm 0.2$ \\
\hline Mean aortic pressure $(\mathrm{mmHg})$ & 5 & $74 \pm 5$ & $72 \pm 3$ \\
\hline $\begin{array}{l}\text { Mean pulmonary arterial pressure } \\
(\mathrm{mmHg})\end{array}$ & 4 & $28 \pm 6$ & $24 \pm 7$ \\
\hline $\begin{array}{l}\text { Mean right atrial pressure } \\
(\mathrm{mmHg})\end{array}$ & 5 & $2 \pm 2$ & $2 \pm 2$ \\
\hline $\begin{array}{l}\text { Mean pulmonary wedge pressure } \\
(\mathrm{mmHg})\end{array}$ & 4 & $4 \pm 3$ & $4 \pm 3$ \\
\hline $\begin{array}{l}\text { Systemic vascular resistance } \\
(\mathrm{mmHg} / \mathrm{liter} / \mathrm{min})\end{array}$ & 5 & $48 \pm 6^{2}$ & $55 \pm 7$ \\
\hline $\begin{array}{l}\text { Pulmonary vascular resistance } \\
\text { (mmHg/liter } / \mathrm{min})\end{array}$ & 4 & $15 \pm 3$ & $16 \pm 3$ \\
\hline
\end{tabular}

\footnotetext{
${ }^{1} P<0.01$.
}

${ }^{2} P<0.05$ collection of expired air, as described above, was included within this plastic bag. The low $\mathrm{O}_{2}$ gas mixture was administered at a flow rate that greatly exceeded the withdrawal rate of the withdrawal pump used for the flow through $\mathrm{VO}_{2}$ measurements, so that room air was not drawn into the plastic bag. Before each measurement of $\mathrm{VO}_{2}$, the inspired fraction of $\mathrm{O}_{2}$ was checked on a sample of inspired gas transferred from the gas mixer to the $\mathrm{O}_{2}$ analyzer. The inspired fraction of $\mathrm{O}_{2}$ varied less than $0.2 \%$ per hour during hypoxia. Similar measurements as above were made at $15,30,45$, and 60 min during hypoxia. For comparison of the responses to hypoxemia at the two different temperatures, 45-min data only were used (Table 2). Before ending the hypoxia after the 60-min measurements, an indocyanine green indicator dilution curve was performed to assess the presence of intracardiac rightto-left or left-to-right shunting and ductal left-to-right shunting. The dye was injected into the proximal hole of the thermodilution catheter situated in the right atrium, and ascending aortic blood was withdrawn through the cuvette densitometer. The entire procedure was repeated 3-4 days later at the other temperature.

We used Student's paired $t$ test to compare values between the two different thermal environments for the resting values, the values after $45 \mathrm{~min}$ of hypoxic exposure, and the \% change in the values from control to $45 \mathrm{~min}$ of hypoxic exposure. Values are reported as mean \pm S.D.

\section{RESULTS}

One lamb died on the fifth day after birth from right ventricular perforation by the thermodilution catheter. The other four lambs were healthy during the week of the studies with normal blood gases and growth rate $(220 \pm 80 \mathrm{~g} /$ day $)$. Once they were blindfolded the lambs rested quietly and often fell asleep during the experiment. There was no apparent difference in the general behavior of the lambs whether they were in the cool or warm environment. Cardiac outputs measured simultaneously by the Fick and thermodilution methods showed an excellent correlation in 52 studies (22 measurements in normoxemia, and 30 during hypoxemia, $\mathrm{y}=1.03 \mathrm{x}+1.34, r=0.92)(15)$.

Resting values in room air at different ambient temperatures (Table 1). When studied, the five lambs were $3.8 \pm 0.8$ days old, weighed $4.5 \pm 0.5 \mathrm{~kg}$ and had a hemoglobin concentration of 8.2 $\pm 0.8 \mathrm{~g} / \mathrm{dl}$. In the cool environment they maintained core temperature without apparent shivering. At the lower ambient temperature the $\mathrm{VO}_{2}$ was $40 \pm 12 \%$ (range +23 to $+52 \%$ ) greater than at the warm temperature. Similarly, arteriovenous blood $\mathrm{O}_{2}$ content difference $(\mathrm{A}-\mathrm{V}$ ) was $19 \pm 12 \%$ (range +7 to $+30 \%$ ) greater and cardiac output $18 \pm 9 \%$ (range +4 to $+33 \%$ ) greater in the cooler temperature. The greater arteriovenous blood $\mathrm{O}_{2}$ content difference was due to a lower mixed venous blood $\mathrm{O}_{2}$ content associated with lower mixed venous $\mathrm{PO}_{2}$ and $\mathrm{O}_{2}$ saturation in the cool environment (Table 1). The greater cardiac output was associated with an increased heart rate $(+14 \pm 8 \%$, range +3 to $+38 \%)$ and little change in stroke volume $(+3 \pm 4 \%$, range -6 to $+13 \%)$. There were no differences in aortic, pulmonary wedge, or right atrial pressures, and the slightly greater pulmonary arterial pressure was not significantly different. Pulmonary vascular resistance was not different, but systemic resistance was significantly lower in the cool environment.

Response to hypoxemia at different ambient temperatures (Table 2). There were no differences in age $(3.8 \pm 1.5$ versus $3.5 \pm 1.3$ days), weight $(4.6 \pm 0.4$ versus $4.4 \pm 0.8 \mathrm{~kg})$ or hemoglobin concentration $(9.5 \pm 3.0$ versus $10.0 \pm 2.0 \mathrm{~g} / \mathrm{dl})$ at the time of study at either temperature.

Although the qualitative responses to hypoxemia were similar regardless of the ambient temperature, the magnitude of some responses were different. During hypoxemia in both environments, the lambs hyperventilated and $\mathrm{PaCO}_{2}$ fell below 30 torr, thereby compensating for the mild metabolic acidosis observed toward the end of the hour of hypoxemia (Table 2). $\mathrm{VO}_{2}$ did not fall significantly in the warm environment $(P<0.1)$, but decreased significantly in the cool environment $(P<0.01)$; the difference was 
Table 2. Response to hypoxemia $\left(\mathrm{FiO}_{2}=0.09\right)$ in four lambs at two different environmental temperatures ${ }^{l}$



Cool Warm

\begin{tabular}{|c|c|c|c|c|}
\hline & & \\
\hline & Control & Hypoxia & Control & Hypoxia \\
\hline $\mathrm{O}_{2}$ consumption $(\mathrm{ml} / \mathrm{min} / \mathrm{kg})$ & $21.5 \pm 0.8 \dagger$ & $16.2 \pm 0.6^{*}$ & $15.4 \pm 1.0$ & $14.5 \pm 0.9$ \\
\hline Core temperature $\left({ }^{\circ} \mathrm{C}\right)$ & $39.6 \pm 0.3$ & $37.5 \pm 0.6^{* *}$ & $39.6 \pm 0.2$ & $39.2 \pm 0.4$ \\
\hline \multicolumn{5}{|l|}{ Arterial } \\
\hline $\mathrm{pH}$ & $7.42 \pm 4$ & $7.41 \pm 2$ & $7.41 \pm 3$ & $7.44 \pm 3$ \\
\hline $\mathrm{PCO}_{2}$ (torr) & $36 \pm 17$ & $27 \pm 3$ & $35 \pm 2$ & $28 \pm 2$ \\
\hline Base deficit & $-2 \pm 3$ & $-6 \pm 2$ & $-2 \pm 2$ & $-5 \pm 2$ \\
\hline $\mathrm{PO}_{2}$ (torr) & $76 \pm 5$ & $28 \pm 3$ & $71 \pm 11$ & $27 \pm 5$ \\
\hline $\mathrm{O}_{2}$ saturation $(\%)$ & $96 \pm 2$ & $54 \pm 7$ & $95 \pm 3$ & $51 \pm 11$ \\
\hline $\mathrm{O}_{2}$ content $(\mathrm{ml} / \mathrm{dl})$ & $12.9 \pm 2.4$ & $7.2 \pm 1.4$ & $12.2 \pm 4.0$ & $6.9 \pm 1.6$ \\
\hline \multicolumn{5}{|l|}{ Mixed venous } \\
\hline $\mathrm{PO}_{2}$ (torr) & $20 \pm 2 \dagger \dagger$ & $10 \pm 1^{*}$ & $27 \pm 1.0$ & $13 \pm 2$ \\
\hline $\mathrm{O}_{2}$ saturation (\%) & $39 \pm 2 \dagger$ & $16 \pm 3$ & $50 \pm 8$ & $18 \pm 3$ \\
\hline $\mathrm{O}_{2}$ content $(\mathrm{ml} / \mathrm{dl})$ & $6.7 \pm 1.8$ & $2.8 \pm 0.7$ & $6.8 \pm 1.4$ & $2.5 \pm 0.6$ \\
\hline$(\mathrm{A}-\mathrm{V}) \mathrm{O}_{2}$ content $(\mathrm{ml} / \mathrm{dl})$ & $6.2 \pm 0.5 \dagger$ & $4.6 \pm 0.5$ & $5.4 \pm 0.6$ & $4.4 \pm 1.2$ \\
\hline Cardiac output (ml/min $/ \mathrm{kg}$ ) & $334 \pm 40+\dagger$ & $361 \pm 44^{*}$ & $295 \pm 46$ & $335 \pm 48$ \\
\hline Heart rate (beats/min) & $230 \pm 20+\dagger$ & $290 \pm 26$ & $195 \pm 10$ & $278 \pm 24$ \\
\hline Stroke volume $(\mathrm{ml} / \mathrm{kg})$ & $1.5 \pm 0.2$ & $1.2 \pm 0.1$ & $1.5 \pm 0.2$ & $1.2 \pm 0.1$ \\
\hline Mean aortic pressure $(\mathrm{mmHg})$ & $73 \pm 5$ & $76 \pm 8$ & $74 \pm 5$ & $73 \pm 10$ \\
\hline $\begin{array}{l}\text { Mean pulmonary arterial pressure } \\
(\mathrm{mmHg})\end{array}$ & $26 \pm 7$ & $49 \pm 4$ & $24 \pm 5$ & $48 \pm 3$ \\
\hline $\begin{array}{l}\text { Mean right atrial pressure } \\
\quad(\mathrm{mmHg})\end{array}$ & $2 \pm 2$ & $1 \pm 4$ & $1 \pm 2$ & $1 \pm 4$ \\
\hline $\begin{array}{l}\text { Mean pulmonary wedge pressure } \\
(\mathrm{mmHg})\end{array}$ & $3 \pm 3$ & $3 \pm 5$ & $3 \pm 3$ & $2 \pm 4$ \\
\hline $\begin{array}{l}\text { Systemic vascular resistance } \\
(\mathrm{mmHg} / \mathrm{liter} / \mathrm{min})\end{array}$ & $49 \pm 6 \dagger$ & $47 \pm 6$ & $54 \pm 7$ & $47 \pm 6$ \\
\hline $\begin{array}{l}\text { Pulmonary vascular resistance } \\
\qquad(\mathrm{mmHg} / \mathrm{liter} / \mathrm{min})\end{array}$ & $16 \pm 3$ & $29 \pm 7$ & $16 \pm 3$ & $30 \pm 9$ \\
\hline
\end{tabular}

${ }^{1}$ Values are taken before and after $45 \mathrm{~min}$ of hypoxemia.

$* P<0.05,{ }^{* *} P<0.01$ between the hypoxemic values at different temperatures.

$\dagger P<0.05$, $\dagger+P<0.01$ between the normoxemic values at different temperatures.

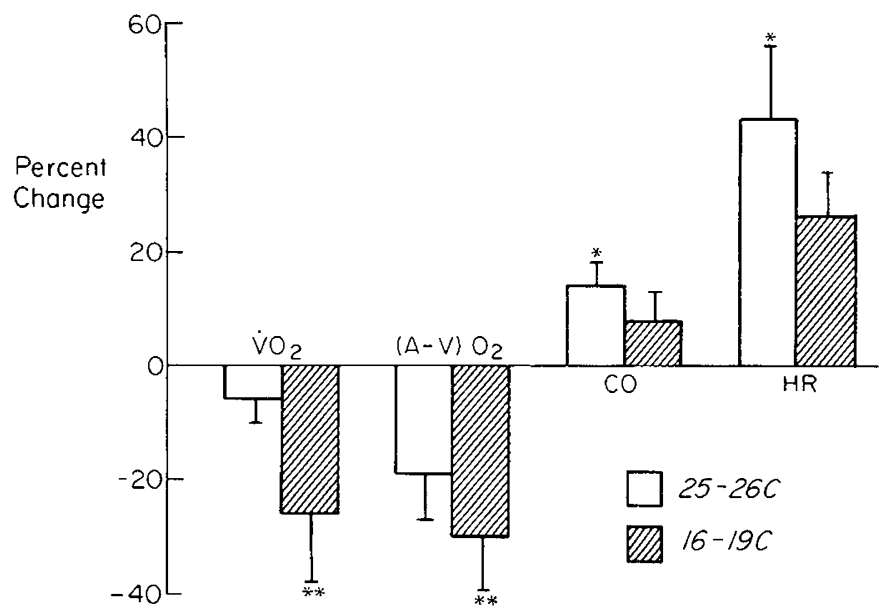

Fig. 1. Changes in $\mathrm{O}_{2}$ consumption $\left(\mathrm{VO}_{2}\right)$, arteriovenous difference in $\mathrm{O}_{2}$ content $(\mathrm{A}-\mathrm{V}) \mathrm{O}_{2}$, cardiac output $(\mathrm{CO})$ and heart rate $(\mathrm{HR})$ during hypoxemia $\left(\mathrm{FiO}_{2}=0.09\right.$ for $45 \mathrm{~min}$ ) in a warm and cool environment. Expressed as $\%$ change from control (mean \pm S.D.). ${ }^{*} P<0.05,{ }^{* *} P<$ 0.01 between $\%$ change at the two different temperatures.

highly significant $(P<0.01)$ (Fig. 1). (A-V) $\mathrm{O}_{2}$ content decreased significantly in both environments $(P<0.01)$, but significantly more in the cool environment $(P<0.01)$ (Fig. 1). Cardiac output did not increase significantly in the cool environment $(P<0.1)$, but rose significantly in the warm environment $(P<0.05)$; the difference was significant $(P<0.05)$ (Fig. 1). Heart rate increased significantly in both environments $(P<0.01)$, but significantly more in the warm environment $(P<0.05)$ (Fig. 1). Core temperature fell to a greater extent during hypoxemia in the cool environment $(P<0.01)$ (Table 2$)$.

These differences in response to hypoxemia occurred within 15 $\mathrm{min}$ and they were maintained during the whole hypoxemic period (Fig. 2). As a result of the differences in the response to hypoxemia, absolute values of $\mathrm{VO}_{2},(\mathrm{~A}-\mathrm{V}) \mathrm{O}_{2}$ content, cardiac output and heart rate at the two temperatures were closer during hypoxemia than during control (Fig. 2). But during hypoxemia, values were still higher in the cooler environment and this was significant for $\mathrm{VO}_{2}$ and cardiac output $(P<0.05)$ (Table 2 , Fig. 2 ).

\section{DISCUSSION}

These studies demonstrate that a small decrease in ambient temperature induces a dramatic increase in $\mathrm{VO}_{2}$, cardiac output, and heart rate in normoxemic newborn lambs, and that these changes were considerably attenuated during acute hypoxemia.

We chose to perform the experiment at $16-19^{\circ} \mathrm{C}$ and $25-26^{\circ} \mathrm{C}$ ambient temperature, because we wanted to simulate situations that occur spontaneously in a laboratory in which ambient temperature is not carefully controlled. The neutral ambient temperature for newborn lambs has been reported to be $30^{\circ} \mathrm{C}$. In preliminary studies, in which ambient temperature was varied between $25-30^{\circ} \mathrm{C}$, we could not demonstrate differences in $\mathrm{VO}_{2}$, cardiac output, or heart rate; we therefore considered that the values were close to minimal at $25^{\circ} \mathrm{C}$.

An important consideration when measuring flows in newborns is the possibility that intracardiac or ductus arteriosus shunting may interfere with the calculation of cardiac output. In this study we could not demonstrate any shunting by indicator dilution curves, and the close relationship between cardiac outputs meas- 

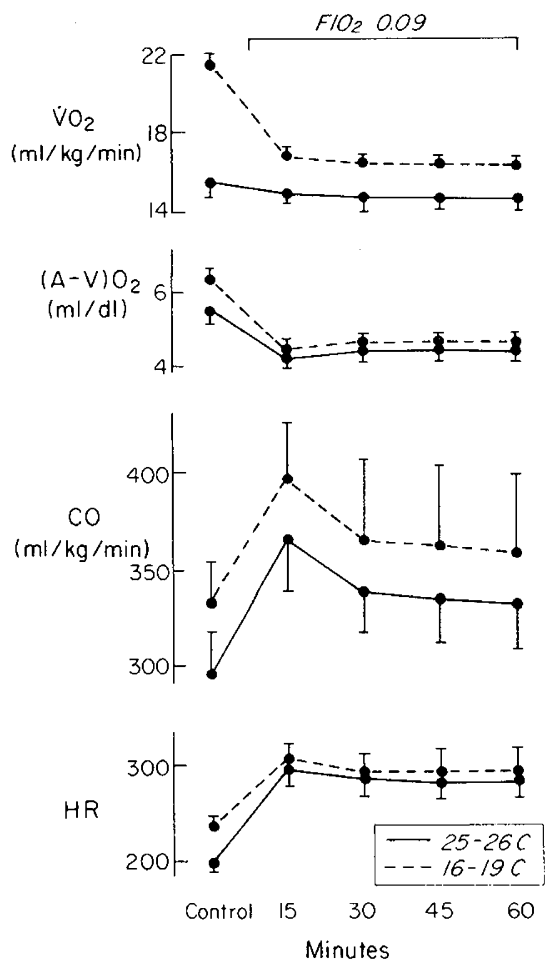

Fig. 2. Changes in $\mathrm{O}_{2}$ consumption $\left(\mathrm{VO}_{2}\right)$, arteriovenous difference in $\mathrm{O}_{2}$ content $(\mathrm{A}-\mathrm{V}) \mathrm{O}_{2}$, cardiac output (CO), and heart rate (HR) during hypoxemia $\left(\mathrm{FiO}_{2}=0.09\right.$ for $45 \mathrm{~min}$ ) in a warm and cool environment. Expressed as absolute values (mean \pm S.D.). Note that the differences in response in regard to temperature occurring within $15 \mathrm{~min}$ after onset of hypoxemia, and the values at different temperatures are closer during hypoxemia than during control (see text).

ured by Fick and thermodilution methods also suggests absence of significant shunting.

Reported values for resting cardiac output in newborn lambs vary from means of about $250(20,25)$ to $400 \mathrm{ml} / \mathrm{kg} / \mathrm{min}(6,13)$, with relatively smaller differences in heart rate (170 to 210$)$. This indicates great variability in stroke volume. Our results indicate that relatively small decreases in ambient temperature can be associated with as much as $20-30 \%$ increase in heart rate and cardiac output. Because stroke volume did not change significantly with ambient temperature, only part of this variation in cardiac output measurements can be explained on the basis of change in ambient temperature alone; other explanations must be found for the variability in stroke volume.

Cardiovascular and metabolic responses of newborn lambs to hypoxemia have varied in different reports. Some investigators demonstrated a large decrease in $\mathrm{VO}_{2}(9)$ with no increase in cardiac output $(9,24)$. Others found only a small decrease in $\mathrm{VO}_{2}$ (18) with a significant increase in cardiac output $(14,18)$. Although there are considerable differences in these studies in terms of sedation, methods of measurements, degree and duration of hypoxemia, our results show that differences in ambient temperature alone might well explain some of this variation. We have shown that, during hypoxemia in a warm environment, there is no significant change in $\mathrm{VO}_{2}$ but a significant increase in cardiac output; although, in a cool environment, there is a large decrease in $\mathrm{VO}_{2}$ and no significant increase in cardiac output (Fig. 1).

During normoxemia core body temperature was maintained without apparent shivering in the cooler environment. This thermal regulation was achieved by increased metabolism, as demonstrated by the $40 \%$ increase in $\mathrm{VO}_{2}$. The increase in heat production may have been achieved by nonshivering thermogenesis with stimulation of brown fat metabolism (12), but also could have resulted from inapparent shivering or "thermal muscular tone" (17). Because we did not obtain electromyographic record- ings, we cannot exclude the latter possibility. Nonshivering thermogenesis is known to be very potent in the newborn lamb and regresses a few weeks after birth (3). Cold exposure is a potent activator of brown fat lipase $(12,21)$, with marked increase in $\mathrm{O}_{2}$ uptake in the brown fat both as a result of an increase in blood flow and $\mathrm{O}_{2}$ extraction (10). During hypoxia, brown fat metabolism is inhibited $(5,10)$ and $\mathrm{O}_{2}$ uptake is decreased in brown fat, as a result of both a decrease in blood flow and in oxygen extraction (10). It is also possible that muscular activity is reduced by hypoxia.

During hypoxemia, core temperature and $\mathrm{VO}_{2}$ both decreased, but the changes were considerably greater in the cool compared with the warm environment. During hypoxemia the differences in $\mathrm{VO}_{2}$ at different ambient temperatures were considerably smaller than during normoxemia, indicating either reduced $\mathrm{O}_{2}$ supply or that most of the change in $\mathrm{O}_{2}$ demand induced by the exposure to a lower temperature was inhibited. Becauuse $\mathrm{VO}_{2}$ was still significantly higher in the cool compared with the warm environment even during hypoxemia, the increase in metabolism associated with exposure to a cool environment was not abolished completely.

As a consequence of the changes in metabolic requirements and $\mathrm{VO}_{2}$, cardiovascular function and blood gases were also influenced by ambient temperature. The $20 \%$ increase in heart rate and cardiac output observed in room air at the lower temperature was probably due to the sympathetic stimulation that mediated the increase in brown fat metabolism (10). Inasmuch as it has been shown that the reserve capacity for increasing cardiac output is decreased in the newborn period, the increase in cardiac output secondary to the exposure to cool environment could considerably affect the potential circulatory reserve of the normoxic newborn. For example, Klopfenstein and Rudolph studied the developmental changes in circulation in the first $6 \mathrm{wk}$ after birth in lambs and found that the newborn lamb had considerably less circulatory reserve capacity than the 3-6-wk-old lamb and was only able to raise cardiac output about $30 \%$ after beta-adrenergic stimulation and $50 \%$ after beta-adrenergic stimulation plus maximum volume loading (13). The $20 \%$ increase in cardiac output induced by exposure to cool environment would limit the capacity for further increases in response to stress. In addition, the increase in (A-V) $\mathrm{O}_{2}$ content in the cool environment was achieved by a decrease in the mixed venous blood $\mathrm{PO}_{2}$ to about 25 torr (Table 2). Because capillary $\mathrm{PO}_{2}$ determines the extraction of $\mathrm{O}_{2}$ in the tissues, the presence of a low mixed venous blood $\mathrm{Po}_{2}$ indicates a limited reserve for increasing $\mathrm{O}_{2}$ extraction. In anemic adult dogs, Cain (8) found that a mixed venous blood $\mathrm{Po}_{2}$ below 40 torr limited $\mathrm{O}_{2}$ supply to some tissues. The combined effects of a decrease in reserve capacity for increasing cardiac output as well as for extracting $\mathrm{O}_{2}$ suggest that there is a very limited reserve for further $\mathrm{O}_{2}$ uptake. Therefore, at lower ambient temperatures additional stress resulting either in an increase in $\mathrm{O}_{2}$ demand or a decrease in systemic $\mathrm{O}_{2}$ transport might produce tissue hypoxia earlier than at a warm temperature. During hypoxemia, however, despite a $40 \%$ decrease in systemic $\mathrm{O}_{2}$ transport, we found no significant difference in the degree of metabolic acidosis (base deficit: 6.0 versus $4.5 \mathrm{meq} / \mathrm{liter} / \mathrm{min}$ ) after $1 \mathrm{~h}$ of exposure in the cool compared with the warm environment (Table 2). The absence of a marked decrease in tolerance to hypoxemia at lower ambient temperatures is probably due to a decrease in $\mathrm{O}_{2}$ requirements secondary to a reduction in thermogenic metabolism associated with the drop in core temperature. Even during hypoxemia, cardiac output was higher in the cool environment indicating a decreased reserve for $\mathrm{O}_{2}$ delivery to tissue; mixed venous blood $\mathrm{PO}_{2}$ and $\mathrm{O}_{2}$ saturation also were lower in the cool environment indicating a decreased reserve for $\mathrm{O}_{2}$ extraction. Therefore, despite the greater drop in core temperature there was no net beneficial effect of the cool environment. It is possible that more severe hypoxemia, colder environment, or decreased insulation of the animals would result in a more substantial drop in core temperature that may decrease basal metabolism enough so that $\mathrm{O}_{2}$ requirement would be less at lower temperature.

This study shows that a decrease of only $7-8 \mathrm{C}$ in ambient 
temperature can induce an increase of $\mathrm{VO}_{2}$ of as much as $30-50 \%$ and a $10-30 \%$ increase in cardiac output and heart rate. There is thus a considerable decrease in the reserve for tissue oxygenation, which is already limited in the newborn. Inasmuch as stroke volume did not change with ambient temperature, only part of the variability reported in normal resting values could be explained by differences in ambient temperature.

We also confirmed that hypoxemia reduces thermogenic metabolism induced by exposure to a cooler environment, and thereby core temperature is not maintained during hypoxemia. We did not find that a cooler environment had a protective effect on tissue oxygenation during hypoxemia; on the contrary, we found that it had a potential deleterious effect by decreasing the reserve for $\mathrm{O}_{2}$ delivery to the tissue, despite the reduced thermoregulation that may expose the newborn to cold injury.

\section{REFERENCES AND NOTES}

1. Adolph, E.: Tolerance to cold and anoxia in infant rat. Am. J. Physiol., 155: 366 (1948)

2. Adolph, E. F.: Response to hypothermia in several species of infant mammals Am. J. Physiol., 166: 75 (1951)

3. Alexander, G.: Body temperature control in mammalian young. Brit. Med. Bull. 31: $62(1975)$.

4. Alexander, G. and Williams, D.: Summit metabolism and cardiovascular function in young lambs during hyperoxia and hypoxia. J. Physiol., 208: 85 (I970).

5. Baum, D., Courtney, L. A., and Stowers, C.: Impairment of cold stimulated lipolysis by acute hypoxia. Am. J. Dis. Child., 121: 115 (1971).

6. Berman, W., Jr. and Musselman, J.: Myocardial performance in the newborn lamb. Am. J. Physiol., 6: H66 (1979).

7. Burton, A. C. and Bronk, D. W.: The motor mechanism of shivering and of thermal muscular tone. Am. J. Physiol., 119: 284 (1937).

8. Cain, S. M.: Oxygen delivery and uptake in dogs during anemia and hypoxia. J. Appl. Physiol., 42: 228 (1977).

9. Cross, K. W., Dawes, G. S., and Mott, J. C.: Anoxia, oxygen consumption and cardiac output in newborn and adult sheep. J. Physiol., 146: 316 (1959).

10. Heim, T. and Hull, D.: The blood flow and $\mathrm{O}_{2}$ consumption of brown adipose tissue in the newborn rabbit. J. Physiol., 186: 42 (1966).

11. Hill, J. R.: The oxygen consumption of newborn and adult mammals. Its dependence on the oxygen tension in the inspired air and on environmenta temperature. J. Physiol., 149: 346 (1959)

12. Hull, D.: The structure and function of brown fat tissue. Brit. Med. Bull., 22: 92 (1966).
13. Klopfenstein, H. S. and Rudolph, A. M.: Postnatal changes in the circulation and response to volume loading in sheep. Circ. Res., 42: 839 (1978).

14. Koiviko, A.: Cardiovascular response of the neonatal lamb to hypoxia, hypercapnia, and metabolic acidosis. Acta Paediatr. Scand. (Suppl.), 191: 1 (1969).

15. Kuipers, J. R. G., Sidi, D., Heymann, M. A., and Rudolph, A. M.: Comparison of methods of measuring cardiac output in newborn lambs. Pediatr. Res., 16: 594 (1982).

16. Lister, G., Hoffman, J. I. E., and Rudolph, A. M.: Oxygen uptake in infants and children: A simple method for measurements. Pediatrics, 53: 656 (1974)

17. Lister, G., Walter, T. K., Versmold, H. T., Dallman, P. R., and Rudolph, A. M.: $\mathrm{O}_{2}$ delivery in lambs: Cardiovascular and hematologic development. Am. J. Physiol., 6: H668 (1979).

18. Lister, G., Frick, K., and Talner, $\mathrm{N}_{\text {.: }} \mathrm{O}_{2}$ transport during hypoxia. Pediatr. Res., 14: $604(1980)$

19. Oliver, T. K., and Karlberg, P.: Gaseous metabolism in newly born human infants: The effects of environmental temperature and $15 \%$ oxygen in the inspired air. Am. J. Dis. Child., 105: 427 (1965).

20. Romero, T. E. and Friedman, W. F.: Limited left ventricular response to volume overload in the neonatal period: A comparison study with the adult animal. Pediatr. Res., 13: 910 (1979).

21. Schiff, D., Stern, L., and Leduc, J.: Chemical thermogenesis in newborn infants: Catecholamine excretion and the plasma nonesterified fatty acid response to cold exposure. Pediatrics, 37: 4 (1966)

22. Scopes, J. W.: Control of body temperature in newborn babies. Sci. Basis Med Anu. Rev. 13: 97 (1970).

23. Scopes, J. W. and Ahmed, I.: Indirect assessment of $\mathrm{O}_{2}$ requirement in newborn babies by monitoring body temperature. Arch. Dis. Child., 41: 25 (1966).

24. Stahlman, M., Gray, J., Young, W. C., and Shepard, F. M.: Cardiovascula response of the neonatal lamb to hypoxia and hypercapnia. Am. J. Physiol., 213: 899 (1967).

25. Toubas, P. L., Hof, R. P., Heymann, M. A., and Rudolph, A. M.: Effect of hypothermia and rewarming on the neonatal circulation. Arch. Franc. Pediatr., 35: 84 (1978).

26. Woods, J. R., Jr., Dandavino, A., Brinkman, C. R. III, Nuwayhid, B., and Assali, N. S.: Cardiac output changes during neonatal growth. Am. J. Physiol., 234: H520 (1978).

27. Current address of D. Sidi: Service de Cardiologie Infantile, Hopital NeckerEnfants Malades, Rue Sevres, Paris 75015, France.

28. Current address of J. R. G. Kuipers: University of Groningen, Academic Hospital, Department of Pediatric Cardiology, Oostersingel 59, $9713 \mathrm{EZ}$, Groningen, The Netherlands.

29. Requests for reprints should be addressed to: Dr. M. A. Heymann, 1403-HSE University of California, San Francisco, CA 94143.

30. This research was supported by U.S. Public Health Service Grant HL 23681 and grants awarded by the French government and the Francis North Foundation (D.S.) and a NATO grant awarded by the Organization for the Advancement of Pure Research-Z.W.P. (J.R.G.K.)

31. Received for publication March 19, 1982

32. Accepted for publication July 2, 1982. 